\title{
IMAN KRISTEN DAN BUDAYA POPULAR
}

\author{
James A. Lola \\ Sekolah Tinggi Agama Kristen Negeri Toraja \\ Jnlola86@gmail.com
}

\begin{abstract}
Humans live in a particular cultural context, on the one side, culture is the result of human creativity, on the other side, culture is also likely affect human. Currently we are in a period of popular culture, popular culture emphasizes the pragmatic attitudes and is controlled by capitalism disguised. The Christians can not be separated from the influence of popular culture, The Christians are called to be able to behave in popular culture without leaving the Christian faith, this article aims to find out how the relationship between Christian faith and popular culture through theological approach.
\end{abstract}

Keywords: popular culture, Christian faith, theology

\begin{abstract}
Abstrak: Manusia hidup dalam konteks budaya tertentu, di satu sisi, budaya adalah hasil dari kreativitas manusia, tetapi di sisi lain, budaya juga cenderung mempengaruhi manusia. Saat ini kita berada dalam masa budaya populer, budaya populer menekankan sikap pragmatis dan dikendalikan oleh kapitalisme yang disamarkan, Orang Kristen tidak lepas dari pengaruh budaya populer, orang Kristen dipanggil untuk dapat berperilaku dalam budaya populer tanpa meninggalkan Iman Kristen, artikel ini bertujuan untuk mencari tahu bagaimana hubungan iman Kristen dan budaya popular melalui pendekatan teologis.
\end{abstract}

Kata kunci: budaya populer, iman Kristen, teologi

Manusia dan kebudayaan (budaya) memiliki hubungan yang cukup unik. Manusia menciptakan kebudayaan namun setelah budaya itu terbentuk maka kebudayaanlah yang pada akhirnya mengatur dan membentuk manusia. Hubungan manusia dan kebudayaan ini merupakan sebuah hubungan dua arah yang bersifat resiprokal dan secara tidak langsung. Hubungan timbal balik ini jugalah yang pada akhirnya memberikan ketegangan-ketegangan yang tidak terelakan dalam kehidupan manusia.

Salah satu ketegangan yang ditimbulkan adalah posisi antara agama dan kebudayaan. Apakah agama juga merupakan produk dari ke- 
budayaan atau sebaliknya, kebudayaan adalah hasil dari agama atau bahkan agama adalah budaya itu sendiri? Apakah agama dapat sejalan dengan kebudayaan atau justru menimbulkan pertengakaran dengan kebudayaan?

Pertanyaan-pertanyaan ini hanyalah secuil pertanyaan di antara begitu banyak pertanyaan mengenai posisi agama dalam hubungan dengan kebudayaan. Umat beragama dituntut untuk dapat memberikan jawaban, sehingga melalu jawaban tersebut dapat ditarik konklusi untuk dapat dijadikan worldview bagi umat beragama untuk bersikap.

Dalam karyanya Richard Niebuhr menjelaskan bahwa hubungan antara Kekristenan dan kebudayaan lebih sering berada pada titik tengkar (Niebuhr, 1951, p. 1). Pada dasarnya, kebudayaan adalah hal yang baik karena merupakan anugerah Allah kepada manusia yang diciptakan segambar dan serupa dengan Allah. Namun sejak kejatuhan manusia ke dalam dosa, kebudayaan seringkali dipakai untuk menunjukkan perlawanan manusia kepada Allah. Oleh sebab itu, kekristenan yang dituntut untuk tetap tetap berada pada kehendak Allah harus berbenturan dengan kondisi dunia yang mulai didominasi oleh kebudayaan yang semakin hari semakin menunjukkan perlawanan kepada kehendak Allah (I Yoh 2:16). Tulisan ini mengkaji tentang bagaimana orang Kristen bersikap dalam menghadapi perkembangan budaya yang saat ini dikenal dengan budaya populer. 


\section{METODE}

Metode yang digunakan dalam penelitian ini adalah kualitatif. Sumber data adalah berbagai literatur yang berkaitan dengan topik ini, juga hasil pengamatan terhadap fakta-fakta atau fenomena-fenomena yang terdapat dalam masyarakat. Pendekatan ini akan menghasilkan data deskriptif berupa kata-kata lisan serta kumpulan perilaku dari masyarakat yang diteliti, secara sistematis, faktual dan akurat. (Suprayogo \& Tobroni, 2003).

\section{HASIL}

Dari sisi ideologi Kristen. Pengaruh budaya populer menjadikan ideologi Kristen mulai "ditinggalkan”. Orang Kristen mulai banyak yang mementingkan pengalaman rohani yang dianggap "spektakuler", seperti yang ditandai dengan kemampuan berbahasa roh. Mereka lebih menyukai pengajaran yang ringan, ketimbang yang berisi pengajaran mengenai pokok-pokok iman Kristen. Intinya, cara beragama menjadi praktis.

Gaya hidup praktis (instant) menjadikan orang Kristen cenderung hanya mengakui kedaulatan Tuhan jika doa mereka terkabul. Gereja semakin bertoleransi terhadap "orang jahat", dan tidak sedikit yang membangun diri menjadi gereja "kaya raya".

Budaya populer telah menggantikan ideologi Kristen dari theosentris menuju antroposentris, dari teologis ke pragmatis. Kekristenan dalam budaya populer hanya sebuah 'sense' dan bukan sebuah identitas. 
Dari sisi epistemologi, tentang bagaimana manusia memperoleh pengetahuan tentang Allah. Seharusnya epistemologi Kristen bersumber pada wahyu Allah, yaitu Alkitab. Akibat pengaruh budaya populer, Alkitab mulai digantikan dengan mode dan tren sesaat. Kebutuhan untuk tentang pengajaran tentang Allah, kehendak Allah, serta apa yang salah dan apa yang benar, mulai memudar digantikan dengan spekulasi psikologis.

Meskipun demikian, umat Kristen tidak perlu alergis terhadap budaya populer. Justeru harus dilihat sebagai pintu masuk untuk pekabaran Injil. Caranya adalah dengan memberikan interpretasi yang tepat terhadap budaya populer dalam terang Firman Tuhan.

\section{PEMBAHASAN}

\section{Pengertian Budaya Populer}

Ada begitu banyak pandangan mengenai apa itu sebenarnya budaya populer, tergantung pada perspektif yang digunakan untuk mendefenisikannya. Menurut Raymond Williams sekurang-kurangnya ada 4 (empat) kriteria yang dapat digunakan untuk mendefenisikan apa itu budaya populer berdasarkan kepada pengertian dari kata populer itu sendiri yakni: (1) banyak disukai orang; (2) jenis kerja rendahan; (3) karya yang dilakukan untuk menyenangkan orang; (4) budaya yang memang dibuat oleh orang untuk dirinya sendiri (Williams, 1983, p. 273).

Berdasarkan keempat kriteria ini dapat diberikan sebuah gambaran sederhana bahwa budaya populer adalah budaya yang disukai oleh banyak orang, tetapi merupakan sebuah budaya rendahan dan ber- 
sifat individual demi mencapai sebuah kepuasaan dan kesenangan. Di sisi yang lain, budaya populer dimaknai sebagai budaya di mana kaum intelektual mempengaruhi masyarakat dalam sebuah komunitas untuk meniru dan mempercayai apa yang mereka lakukan sebagai kebenaran melalui media massa terutama melalui media elektronik. Tony Bernet mengatakan,

Budaya pop dibangun oleh sekelompok orang atau penguasa untuk memenangkan hegemoni mereka, sembari membentuk lawan. Dengan demikian ia terdiri bukan hanya dari pemberlakuan budaya massa yang sejalan dengan ideologi dominan ataupun budaya oposisional yang spontan, melainkan sebagai area negosiasi antara keduanya di mana - beberapa tipe budaya yang berbeda dari budaya pop yang dominan, dengan budaya yang subordinan dan oposisional dengan segenap nilai-nilai dan unsurunsur ideologis yang tercampur dalam suatu perubahan yang bersifat sekuensial. (Bernet, 1992, pp. xv-xvi)

Hal ini berarti bahwa dalam perkembangan budaya populer ada beberapa unsur yang sangat berperan dalam membentuk dan menyebarkan budaya populer ini yaitu (1) kelompok intelektual yang sering disebut dengan kelompok elite sebagai kelompok yang menciptakan (2) kelompok penerima sebagai mereka yang meneruskan budaya populer (3) kelompok oposisi sebagai mereka yang ikut membantu untuk mempopulerkan kebudayaan yang dibuat kelompok elit dan yang terakhir adalah (4) media massa sebagai media untuk menyebarkan budaya tersebut.

Berdasarkan kepada empat unsur dari perkembangan budaya populer ini, bisa dikatakan bahwa sebenarnya budaya populer merupakan sebuah budaya klise, karena sebenarnya keempat unsur ini 
masih tergerus pada arus utama modernisasi yaitu kapitalisme, teknologi, urbanisasi dan telekomunikasi.

Pada unsur pertama, terlihat dengan jelas bagaimana kapitalisme muncul sebagai suatu kekuatan yang mengakibatkan adanya kebergantungan-kebergantungan dalam bentuk kebebasan-kebebebasan yang lebih bersifat klise, hal ini terlihat dalam belum tersebarnya teknologi secara merata pada masyarakat sehingga hanya mereka yang memiliki kekuatan saja yang dapat mereorganisasi struktur sosial (sistem -sistem). Singkatnya mereka yang memiliki power akan menguasai sistem-sistem, dan karena sistem-sistem sedemikian melingkupi seluruh warga, para operator sistem-sistem ini memiliki akses pada kehidupan warga biasa dan mengontrol kehidupan warga.

Dapat dikatakan bahwa para kaum kapitalis ini adalah para imam besar yang dapat membuat segala kemungkinan di antara kehidupan dan kekacauan, mereka dapat membuat segala kekacauan dalam segala kemungkinan kehidupan dengan memberikan kehidupan yang tidak pasti, dan hanya mempunyai sedikit pedoman dan petunjuk sehingga melaluinya mereka dapat mengontrol untuk tujuan manufaktur, produksi dan konsumsi, merekalah yang menentukan arah kehidupan kita, menentukan nilai-nilai serta pengharapan-pengharapan kita supaya dapat menyesuaikan dengan lingkungan publik mereka. Pendeknya, kehidupan menjadi seperti sebuah mesin yang disetel secara halus.

Kedua, teknologi menjadi hal penting berikutnya dalam budaya populer karena merupakan sarana yang juga sangat berperan signifikan 
bagi kapitalisme. Teknologi juga memiliki sumbangsih dalam merasionalisasi kehidupan, membentuk sebuah masyarakat yang berpikir naturalistis dengan pemikiran bahwa apa yang paling efisien adalah yang paling etis (Welss, 2005, p. 10).

Dunia menjadi bersifat mekanistik dan opportunistik, meminjam bahasa Berger dalam bukunya bahwa ini yang disebut dengan 'krisis kemasukakalan' (Berger, 1969, p. 172), karena masyarakat mulai terstrukturualisasi secara teknologi dalam jaringan eksternal yang pada akhirnya mengenyahkan nilai-nilai dan makna-makna dalam diri.

Ketiga, urbanisasi sebagai bagian dari pembentukan budaya populer. Perkembangan budaya populer diteruskan juga melalui pertumbuhan urbanisasi. Hal ini tidak ditentukan oleh besarnya sebuah kota melainkan pada ukuran dan dominasi sosial dari kota-kota tersebut (Buckner \& Palen, 2006). Melalui pembentukan lingkungan-lingkungan psikologis dengan wawasan dunia yang beraneka ragam. Lingkungan multikultural ini pada akhirnya menghasilkan sebuah kultur baru yang memberikan tuntutan yang kuat pada pluralisme yang menghasilkan relativisme yang menyeluruh.

Keempat adalah media massa (telekomunikasi). Dari keempat unsur pembentuk budaya popular, media massa menjadi faktor penentu utama dalam hal mempopulerkan suatu produk budaya. Media berperan sebagai produsen sekaligus sebagai distributor informasi, juga sebagai agen utama dalam membentuk kebenaran dan opini publik yang kemudian berkembang menjadi kebenaran bersama. Bertahannya sebuah 
kebudayaan dan nilai kebenaran tergantung pada seberapa besar dan kuatnya media massa mempromosikannya, karena apapun yang diproduksi dan disebarkan oleh media akan diterima sebagai kebenaran.

Dengan kata lain, jika ingin menilai atau mencermati struktur dan posisi sebuah masyarakat cukup untuk mengamati budaya apa yang sedang berkembang dan dikendalikan oleh media. Hal ini membuat media menjadi bagian dari salah satu institusi yang kuat di masyarakat, karena media massa menjadi otoritas tunggal yang menyeleksi, memproduksi pesan, dan menyampaikannya pada khalayak. Mc Quail dalam bukunya Mass Communication Theories, merangkum beberapa pandangan terhadap peran media massa. Setidaknya ada enam perspektif dalam melihat peran media.

Pertama, melihat media massa sebagai window on event and experience. Media dipandang sebagai jendela yang memungkinkan khalayak "melihat" apa yang terjadi di luar sana. Media juga merupakan sarana belajar untuk mengetahui berbagai peristiwa.

Kedua, media sering dianggap sebagai a mirror of events in society and the world, implying a faithful reflection. Cermin berbagai peristiwa yang ada dimasyarakat dan dunia, yang merefleksikan apa adanya.

Ketiga, memandang media massa sebagai filter, atau gate keeper, yang menyeleksi berbagai hal untuk diberi perhatian atau tidak. Media senantiasa memilih issue, informasi atau bentuk content lain berdasar standar para pengelolanya. Di sini khalayak "dipilihkan" oleh 
media tentang apa-apa yang layak diketahui dan mendapat perhatian.

Keempat, media massa acapkali dipandang sebagai guide, petunjuk jalan atau interpreter, yang menerjemahkan dan menunjukkan arah atas berbagai ketidakpuasan atau alternatif yang beragam.

Kelima, media massa sebagai forum untuk mempresentasikan berbagai informasi dan ide-ide kepada khalayak, sehingga memungkinkan terjadinya tanggapan dan umpan balik.

Keenam, media massa sebagai interlocutor, yang tidak hanya sekedar tempat berlalu lalangnya informasi, tetapi juga partner komunikasi yang memungkinkan terjadinya komunikasi yang interaktif (McQuail, 2003, p. 12).

Jadi peran media massa dalam kehidupan sosial bukan sekedar sarana hiburan semata, tetapi isi dan informasi yang disajikan oleh media massa memiliki peran yang signifikan dalam proses perkembangan sosial terutama sebagai pembentuk opini dan kebenaran publik. Isi media merupakan konsumsi otak bagi khalayaknya, sehingga apa yang ada di media massa akan mempengaruhi mereka.

David F Wells mengomentari hal ini dengan baik dalam bukunya Tiada Tempat bagi Kebenaran.

Sebuah peradaban baru sedang bangkit, dan semua perubahan ini menandai pengaruhnya. Tidak seperti kerajaan dan kekaisaran masa lampau, perdaban ini tidak berpusat pada bangsa tertentu atau berakar pada satu tempat tertentu di bumi, serta tidak bernatur politik. Peradaban ini berkembang cepat di tanah yang menghasilkan demokrasi dan kapitalisme, dan ia amat bergantung pada perkembangan teknologi dan urbanisasi. Tetapi di mana pun peradaban ini hadir, ia sanggup mengatasi batas dan tempat, juga bahasa dan kebiasaan, sebab ia dibawa oleh demokrasi dan kapitalisme, teknologi dan kota besar, dan semua ini dengan cepat 
menjadi fenomena universal. Semua ini adalah bahasa dunia modern, bahasa setiap orang, sebab ia bukan milik siapapun secara khusus (Wells, 2004, p. 10).

Pengaruh media ini pada akhirnya membawa transformasi yang bersifat revolusioner atas dunia kita, yang secara tidak langsung menghasilkan perubahan-perubahan baik dari sisi luar kehidupan kita, atau bahkan perubahan pada nilai-nilai dan makna di dalam diri kita.

Jadi sebuah budaya popular dapat dikategorikan sebagai sebuah budaya yang diikuti atau disukai banyak orang karena mudah dinikmati dan diadopsi oleh publik dengan mudah dan budaya popular tersebut dibangun berdasarkan pada upaya untuk peningkatan kenyamanan diri.

\section{Iman dan Praksis Kristen dalam Budaya Populer}

Perkembangan budaya populer ini, dari waktu ke waktu semakin tidak terbendung. Tidak hanya menawarkan berbagai aneka macam produk tetapi juga telah menciptakan suatu gaya hidup tersendiri. Dalam hal ini, budaya populer telah melahirkan sebuah generasi baru dalam sejarah peradaban manusia. Bisa disimpulkan bahwa sebenarnya budaya populer adalah sebuah 'attitude of mind,' sebuah ideologi dan metodologi dalam kehidupan manusia di masa kini untuk menemukan realitas kehidupan.

Kekristenan sendiri tidak terlepas dari pengaruh budaya populer. Ini dapat diukur dalam berbagai cara, tetapi yang paling menarik diantaranya adalah pergeseran pada ideologi dan epistemologi. 
Kekristenan sendiri tidak terlepas dari pengaruh budaya populer. Ini dapat diukur dalam berbagai cara, tetapi yang paling menarik diantaranya adalah pergeseran pada ideologi dan epistemologi.

\section{Ideologi}

Ideologi dimaknai secara umum sebagai suatu kumpulan ide, keyakinan serta kepercayaan yang mengarahkan tingkah laku seseorang dalam bidang kehidupan. Dengan kata lain, ideologi adalah worldview. Suatu Ideologi pada hakikatnya bersiat prateoritis, mendahului tindakan berpikir kita. Ideologi menentukan apa yang kita anggap paling penting untuk dipikirkan dan dilakukan.

Kekristenan sendiri berkembang di atas sebuah dasar agung yang diakui sebagai sebuah kebenaran yang ultimat, kompeherensif dan obyektif yang dipersonifikasikan oleh Yesus Kristus.

Dalam kekristenan, dikonsepkan bahwa dunia yang ada pada saat ini, diciptakan dalam kondisi yang sungguh amat baik dan berada pada pemerintahan Allah melalui manusia sebagai wakilnya yang diciptakan segambar dan serupa dengan-Nya. Namun akibat kejatuhan manusia ke dalam dosa, gambar dan rupa Allah mengalami kerusakan secara total dan efeknya juga menimpa kepada dunia sebagai ciptaan Allah. Akibatnya dunia mengalami kemerosotan secara perlahan-lahan yang ditandai dengan terus diberikannya hukuman oleh Allah kepada manusia dan alam semesta.

Tetapi, kisah Alkitab yang dijadikan sebagai ideologi bagi orang 
percaya juga mencatat bahwa Allah terus berusaha untuk memperbaharui hubungan manusia. Dimulai dengan penyelamatan Nuh dalam kisah Air Bah untuk meneruskan tugas manusia di bumi dalam hal memelihara dan mengusahakan bumi, dilanjutkan melalui pemanggilan Abraham untuk menjadi umat pilihan Allah.

Kisah Allah yang terus berkarya untuk menyelamatkan manusia terlihat semakin jelas dalam exodus bangsa Israel dari Tanah Mesir, Allah memperlihatkan keagungan dan kemahakuasaan-Nya dalam mengatur alam semesta untuk tunduk pada otoritas dan kehendak-Nya.

Hal ini berlanjut dalam sejarah bangsa Israel, di mana Allah mengatur sejarah kehidupan manusia untuk menunjukkan supremasi Allah atas seluruh bangsa dan seluruh dunia. Allah berhak untuk mengangkat dan menurunkan seseorang dari posisinya sebagai seorang raja/penguasa.

Puncak dari karya Allah adalah dengan pengutusan Yesus Kristus ke dalam dunia untuk menebus dosa seluruh umat manusia melalui kematian dan kebangkitan-Nya.

Dari hal ini tergambar dengan jelas ideologi pertama dari kekristenan yaitu bahwa Allah berdaulat penuh di dalam dunia untuk mengatur jalannya seluruh sejarah dunia untuk memperbaharui umat manusia dan segala sesuatu. Abraham Park mengatakan,

Setelah kejatuhan Adam ke dalam dosa, seluruh sejarah umat manusia yang dirancang oleh Allah Bapa, yang digenapkan oleh Yesus, Anak Allah, dan yang disempurnakan oleh Roh Kudus adalah sejarah penebusan yang mengalir di dalam penyelenggaraan Allah. (Park, 2010, p. 32). 
Hal kedua yang menjadi pokok dalam inti iman Kristen adalah tentang Yesus Kristus sebagai satu-satunya jalan keselamatan manusia untuk sampai kepada Allah. Karya Kristus yang adalah manusia sejati dan Allah sejati terlihat jelas dalam penggenapan dan penerapan penebusan yang dikerjakan di kayu salib. Melalui salib, Kristus menerima kutukan yang seharusnya diterima oleh manusia karena perbuatan dosa dan karena pelanggaran hukum Taurat.

Pokok ketiga adalah Alkitab sebagai Firman Allah. Alkitab memiliki semua penjelasan akan semua interpretasi manusia yang benar dan bermakna tentang realitas. Dalam Alkitab, peristiwa-peristiwa yang bersifat penyataan tentang semua realitas termasuk mencakup semua narasi tentang kejadian historis yang aktual disertai makna-maknanya dijelaskan dengan begitu detail (Crampton, 2002), sehingga dari penyataan Alkitab inilah epistemologi Kristen secara intim dibangun dan disusun. Konsekuensi dari pernyataan ini adalah bahwa pandangan seseorang terhadap Alkitab akan sangat mempengaruhi pandangannya terhadap keseluruhan realitas yang dialaminya, termasuk realitas metafisik.

Inti keyakinan Kristen bersumber dari Alkitab yang adalah mutlak penting. Jika Alkitab diabaikan, pastilah gereja dan iman Kristen akan mengalami kecelakaan. Kedudukan Alkitab yang tertinggi itu dicermin secara praktis dalam kehidupan orang percaya (Barr, 1997).

Pandangan terhadap Alkitab juga berpengaruh terhadap bagaimana ia mempergunakan Alkitab itu untuk memperoleh pengetahu- 
an tentang Allah. Iman Kristen percaya bahwa Alkitab adalah wahyu Allah yang di dalamnya dinyatakan tentang natur dan sifat Allah sehingga melaluinya manusia dapat memperoleh pengetahuan tentang Allah yang sejati.

Alkitab mengajarkan bahwa Allah menyatakan diri-Nya kepada manusia karena anugerah-Nya (UI. 7:7-8; Tit. 6:5). Allah menghendaki manusia mengenal Dia, bukan hanya secara intelektual dan abstrak saja, tetapi lebih secara eksperensial dan personal. (Hoffecker, 2010).

Alkitab memenuhi kebutuhan manusia untuk mengetahui Allah secara ekperensial dan personal. Dengan mengklaim Alkitab adalah Firman Allah, orang Kristen memaksudkan bahwa Allah bukan hanya menyatakan kebenaran tertentu atau partial tentang diri-Nya saja tetapi la juga menginterpretasikan isi penyataan-Nya bagi manusia sehingga manusia mampu memahaminya.

Singkatnya, ideologi dari iman Kristen adalah semata-mata melihat bahwa semua yang terjadi dalam kehidupan manusia adalah anugerah dari Allah dan bukan hasil usaha manusia. Kekristenan bersumber dari inisiatif dan penyataan diri Allah sendiri dan bukan berdasarkan kapasitas manusia. Semenjak manusia jatuh dalam dosa maka tidak ada satu pun kapasitas asali manusia yang dapat dibanggakan. Kredo yang terkenal dari iman Kristen adalah bahwa segala sesuatu bersumber dari Allah dan dikembalikan untuk kemuliaan Allah.

Dalam budaya populer, ideologi kekristenan dipertanyakan. Bah- 
kan tampaknya perlahan namun pasti mulai ditinggalkan, digusur dari pusatnya dan digantikan dengan 'dongeng' hasil rekaan para kaum kapitalisme. Memang ajaran-ajaran dan pokok iman Kristen ini masih diakui, namun strukturnya sudah terpotong-potong sehingga sesuatu yang bukan teologi telah menjadi pusat iman dari 'komunitas popular'.

Yang paling terlihat sebagai hasil dari budaya populer dapat ditemukan dalam perkembangan kekristenan di mana terjadi gerakan yang menekankan pada pentingnya sebuah pengalaman rohani yang bersiat spektakuler yang harus ditandai dengan kemampuan berbahasa roh. Jemaat lebih menyukai khotbah-khotbah yang penuh dengan guyonan seperti sebuah acara stand up comedy ketimbang sebuah khotbah yang berisi pengajaran mengenai pokok-pokok iman Kristen. Kebaktian-kebaktian menjadi lebih bersifat bisnis ketimbang religius. Singkatnya, tidak ada yang tersisa dalam teologi kecuali praktik.

Allah dijadikan seperti sebuah mesin penjawab doa yang dapat mengabulkan semua permintaan manusia. Yesus dipandang hanya sebagai seorang penyembuh yang harus menyembuhkan semua penyakit. Gereja telah menjadi tempat yang nyaman untuk menyembunyikan para pelaku kejahatan. Bahkan lebih dari itu, gereja kini seperti menjadi sebuah industri besar yang berusaha menimbun kekayaan sebanyak mungkin. Tidak ada lagi pengajaran mengenai Allah Tritunggal, Yesus sebagai juruselamat, dan penggalian Alkitab.

Kualitas-kualitas para pelayan pun sekarang tergerus pengaruh budaya populer. Jika dulu untuk menjadi seorang pelayan (pendeta) di- 
haruskan untuk setidaknya mencapai gelar sarjana dengan studi yang cukup lama, saat ini, dengan cukup hanya dengan penambahan beberapa mata kuliah saja yang tidak jauh berbeda dengan mata kuliah penyegaran seseorang langsung dapat mencapai gelar doktor di bidang teologi.

Kebangkrutan-kebangkrutan ini menyebar bagaikan virus yang tidak dapat disembuhkan sehingga pada akhirnya kepekaan terhadap kebenaran pun hilang. Kebenaran yang bersifat absolut kini menjadi relatif. Kemahakuasaan Allah dalam budaya populer digantikan dengan kekuasaan-kekuasaan manusia.

Budaya populer telah menggantikan Ideologi kekristenan dari theosentris menuju antroposentris, dari teologis ke pragmatis. Kekristenan dalam budaya populer hanya sebuah 'sense' dan bukan sebuah identitas.

\section{Epistemologi}

Epistemologi adalah kajian filosofis yang merupakan telaah kritis dan analitis tentang dasar-dasar teori pengetahuan. Epistemologi kadang disebut teori pengetahuan. Sebagai cabang ilmu filsafat, epistemologi mengkaji dan mencoba menemukan ciri-ciri umum dan hakikat pengetahuan manusia, dari mana sumber pengetahuan, serta batasanbatasan pengetahuan manusia. Epistemologi juga bermaksud mengkritisi asumsi-asumsi dan syarat-syarat kelogisan yang mendasari dimungkinkannya pengetahuan. Juga mencoba memberi pertanggungjawaban yang rasional terhadap klaim kebenaran. Sebab itu, epistemolo- 
gi adalah suatu disiplin ilmu yang bersifat evaluatif, normatif, dan kritis. (Sudarminta, 2002, p. 19).

Dalam filsafat kebenaran memiliki begitu banyak klasifikasi dari, dan pembagian wilayah kebenaran yang masing-masing memiliki skop tersendiri, dan tidak bersifat mutlak atau kebenaran itu sangat bergantung pada situasi pada saat itu. Kebenaran tertinggi bagi filsafat adalah kebenaran yang ditemukan dengan penggunaan kapasitas kemampuan natural manusia tanpa bantuan dari luar diri manusia. Sehingga melalui asumsi ini maka pola pendekatan terhadap metode untuk pengetahuan pun berbeda.

Pada permulaan epistemologi pokok persoalan bukan pada apa yang diyakini melainkan apa yang dibenarkan untuk diyakini, sehingga dari pandangan ini muncullah skeptisisme yang menegaskan bahwa tidak ada satu hal pun yang dapat dipercayai sebagai kebenaran sebelum diuji kebenarannya (Geisler, 2002).

Dalam kaitan dengan iman Kristen, epistemologi adalah tentang bagaimana manusia memperoleh pengetahuan tentang Allah. Jadi, epistemologi harus bersumber dari wahyu Allah itu sendiri yaitu Alkitab. Alkitab merupakan solusi bagi pandangan humanistis yang diekspresikan sepanjang sejarah Barat. Kekristenan menawarkan suatu cara berpikir yang berbeda dengan pemikiran non-kristen, dengan memakai suatu pendekatan theistis tentang realitas yang diajarkan oleh Alkitab. (Hoffecker, 2010).

Kekristenan mengakui, seluruh pengetahuan manusia, baik ter- 
hadap realitas di dunia ataupun realitas metafisik, bersumber dari Alkitab. Alkitab memuat secara menyeluruh semua dasar dari aktifitas yang ada di dalam dunia ini dari penciptaan hingga pada akhir dunia. Juga memuat tentang kemungkinan pengetahuan manusia akan Allah, tentang sifat dan karya-Nya yang dinyatakan dalam dunia. Alkitab berbicara tentang ratusan tema yang kontroversial secara harmonis dan konsisten. (McDowell, 2002).

Begitu juga pengetahuan akan Allah, Alkitab memberikan begitu banyak pemaparan tentang hakikat dan sifat Allah, sehingga melaluinya manusia dapat memperoleh pengetahuan tentang Allah yang sejati. Penyataan dari Allah merupakan sumber pengetahuan tentang Allah. Akibat dosa maka manusia dengan kemampuannya sendiri tidak akan dapat memperoleh pengetahuan akan Allah, hanya melalui penyataan Allah.

Tetapi dalam pengaruh budaya populer, Alkitab sebagai Firman Allah digantikan dengan mode dan tren sesaat, serta serpihan-serpihan budaya massa. Budaya populer seakan tidak memperdulikan mengenai informasi yang dia terima. Bagi para pengikutnya yang terpenting adalah sesuatu yang sedang tren dan mengemuka pada saat itu. Tidak ada lagi pengajaran tentang apa yang salah dan apa yang benar sesuai dengan ajaran Alkitab, justru digantikan dengan spekulasi psikologis.(Wells, 2004).

\section{KESIMPULAN}

Jika demikian bagaimanakah seharusnya iman Kristen di tengahtengah budaya popular? Rasul Paulus mengatakan kepada jemaat di 
bahwa "supaya kamu tiada beraib dan tiada bernoda, sebagai anak-anak Allah yang tidak bercela di tengah-tengah angkatan yang bengkok hatinya dan yang sesat ini, sehingga kamu bercahaya di antara mereka seperti bintang-bintang di dunia, sambil berpegang pada firman kehidupan." (Fil 2:15-16)

Dalam hal ini, orang kristen dipanggil untuk tetap mewartakan kesaksian iman di tengah-tengah budaya populer dengan tidak merubah atau terjerembab dalam ideologi dan epistemologi budaya popular yang lebih menekankan tren dan keuntungan baik secara finansial semata atau yang berisfat konsumtif. Sebaliknya menjadi tugas umat Kristen untuk menemukan dan mengartikulasikan jalan hikmat melalui pementasan kehidupan. (Vanhoozer, 2002).

Memang budaya populer dengan media massanya telah berhasil memberikan apa yang manusia inginkan dengan menciptakan atau membentuk sebuah realitas baru. Namun seperti yang dijelaskan oleh Carl Henry yang dikutip oleh Vanhoozer bahwa "setiap kebudayaan memiliki 'suatu keyakinan perekat, yaitu pandangan mendasar terhadap kehidupan dan realitas yang melestarikan kesatuan mereka”. Artinya, setiap kebudayaan selalu mempunyai kepercayaan/keyakinan terhadap realitas yang tidak terlihat. Budaya populer juga memiliki suatu realitas tak terlihat yang telah dijadikan sebagai sebuah perekat dan kepercayaan. Realitas yang tidak terlihat inilah yang dapat dijadikan sebagai pintu masuk bagi iman Kristen.

Iman Kristen harus dapat memberikan interpretasi yang tepat kepada Firman Tuhan dan juga memberikan interpretasi kepada dunia 
populer. Iman kristen tidak perlu anti terhadap budaya populer. Sebaliknya iman Kristen harus dapat menasirkan budaya populer tersebut dengan baik dalam terang penafsiran Firman Tuhan yang benar.

Selain itu, kekristenan juga harus dapat memperlihatkan sebuah praksis kehidupan yang mencerminkan inti iman tersebut, karena pola pikir budaya populer yang lebih menekankan pada praktis ketimbang teologis. Sikap praktis harus terlebih dahulu diletakkan di atas suatu prinsip teologis yang ketat.

\section{DAFTAR PUSTAKA}

Barr, J. (1997). Alkitab di Dunia Modern. Jakarta: BPK Gunung Mulia.

Berger, P. L. (1969). The Sacred Canopy: Elements Of a Sociology of Religion. New York: Doubleday.

Bernet, T. (1992). Popular Culture: Defining Our Terms. In Popular Culture: Themes and Issues (1st ed.). London: Open University Press.

Buckner, H. T., \& Palen, J. J. (2006). The Urban World. In Contemporary Sociology (Vol. 5). https://doi.org/10.2307/2063174

Crampton, W. G. (2002). Verbum Dei. Surabaya: Momentum.

Geisler, N. L. (2002). Filsafat dari Perspektif Iman Kristen. Malang: Gandum Mas.

Hoffecker, W. A. (2010). Membangun Wawasan Dunia Kristen. Surabaya: Momentum.

McDowell, J. (2002). Apologetika Dasar. Malang: Gandum Mas.

McQuail, D. (2003). Mass Communication Theories (5th ed.). London: Sage Publication.

Niebuhr, H. R. (1951). Christ and Culture. New York: Harper and Row.

Park, A. (2010). Silsilah di Kitab Kejadian. Jakarta: Grasindo. 
Suprayogo, I., \& Tobroni. (2003). Metodologi Penelitian Sosial-Agama. Bandung: Rosdakarya.

Vanhoozer, K. J. (2002). Dunia dipentaskan dengan Baik? Teologi, Kebudayaan, dan Hermeneutika. In Allah dan Kebudayaan (1st ed.). Surabaya: Momentum.

Wells, B. D. F. (2004). No Place for Truth. Surabaya: Momentum.

Welss, D. F. (2005). Allah di Lahan Terbengkalai. Surabaya: Momentum.

Williams, R. (1983). Keyword. London: Fontana. 